\title{
UPAYA MENINGKATAN KEMAMPUAN MENENTUKAN UNSUR-UNSUR INTRINSIK CERITA RAKYAT SISWA KELAS III SD NEGERI 25 LUBUKLINGGAU MELALUI MODEL PEMBELAJARAN KOOPERATIF TIPE THINK PAIR AND SHARE (TPS)
}

\author{
Siti Zubaidah \\ SD Negeri 25 Lubuklinggau \\ sitizubaidah2018@gmail.com
}

\begin{abstract}
ABSTRAK
Tujuan penelitian ini adalah untuk membuktikan bahwa melalui model pembelajaran kooperatif tipe Think Pair and Share (TPS) dapat meningkatkan kemampuan siswa kelas III SD Negeri 25 Lubuklinggau dalam menentukan unsur-unsur intrinsik cerita rakyat. Metode yang digunakan dalam penelitian ini adalah metode Penelitian Tindakan Kelas (PTK) yang diawali oleh data pratindakan dan dua kali pelaksanaan siklus penelitian. Hasil data tes pada pratindakan dari 36 siswa, siswa yang mendapat nilai 65 atau telah tuntas sebanyak 21 orang atau 58,33\% dari jumlah siswa. Sedangkan siswa yang mendapat nilai kurang dari 65 atau belum tuntas sebanyak 15 orang atau 41,67\%, dengan nilai rata-rata kelas 61,25. Pada siklus I terjadi peningkatan perolehan nilai. Siswa yang telah tuntas sebanyak 26 siswa atau 72,22\% sedangkan yang belum tuntas sebanyak 10 orang atau $27,78 \%$ dengan nilai rata-rata 66,53 . Ini terjadi peningkatan sebesar 5,28 atau $8,62 \%$. Siklus II juga mengalami peningkatan, dari 36 siswa yang telah tuntas sebanyak 33 siswa atau $91,67 \%$ dan yang belum tuntas sebanyak 3 siswa atau 8,33\% dengan nilai rata-rata 75,69. Jika dihitung peningkatan dari nilai pratindakan sampai siklus II terjadi peningkatan sebesar yaitu $16,1 \%$. Dengan demikian hipotesis yang dikemukan dalam penelitian ini terbukti, bahwa dengan penerapan model pembelajaran kooperatif tipe Think Pair and Share (TPS) dapat meningkatkan kemampuan menentukan unsur-unsur intrinsik dalam cerita rakyat siswa III SD Negeri 25 Lubuklinggau.
\end{abstract}

Kata Kunci : Model Kooperatif, Think Pair and Share, Unsur-unsur Intrinsik.

\section{ABSTRACT}

The purpose of this research is to prove that through cooperative learning model of Think Pair and Share (TPS) type can improve the ability of third grade students of SD Negeri 25 Lubuklinggau in determining the intrinsic elements of folklore. The method used in this research is Classroom Action Research method (PTK) which is preceded by pratindakan data and twice the implementation of the research cycle. Results of test data on pratindakan of 36 students, students who scored 65 or have completed as many as 21 people or $58.33 \%$ of the number of students. While students 
who scored less than 65 or not completed as many as 15 people or $41.67 \%$, with an average grade grade of 61.25. In the first cycle there is an increase in value gains. Students who have completed as many as 26 students or $72.22 \%$ while unfinished as many as 10 people or $27.78 \%$ with an average score of 66.53 . This is an increase of 5.28 or $8.62 \%$. Cycle II also increased, from 36 students who have completed as many as 33 students or $91.67 \%$ and unfinished as many as 3 students or $8.33 \%$ with an average value of 75.69. If the calculated increase from the pre-action value until the second cycle there is an increase of $16.1 \%$. Thus, the hypothesis that is found in this research is proved, that with the implementation of cooperative learning model Think Pair and Share (TPS) can improve the ability to determine the intrinsic elements in folklore students III SD Negeri 25 Lubuklinggau.

Keywords: Cooperative Model, Think Pair and Share, Intrinsic Elements.

\section{PENDAHULUAN}

Dalam dunia pendidikan, ada sebuah paradigma lama mengenai proses belajar mengajar, paradigma yang bersumber pada asumsi tabula rasa John Locke. Locke mengatakan bahwa pikiran seorang anak adalah seperti kertas kosong yang putih bersih dan siap menunggu coretan-coretan dari gurunya. Dengan kata lain, otak seorang anak adalah ibarat botol kosong yang siap diisi dengan segala ilmu pengetahuan dan kebijaksanaan sang guru.

Pola pengajaran yang banyak diterapkan pada saat sekarang ini adalah pola yang mengacu pada paradigma lama, yaitu pola pengajaran klasikal yang lebih berpusat pada guru di depan kelas sebagai sumber utama pengetahuan. Ceramah menjadi strategi utama dalam proses pembelajaran tanpa memperhatikan kecerdasan siswa. Model pembelajaran yang kurang tepat menyebabkan rendahnya motivasi dan hasil belajar siswa. Pola seperti ini juga diterapkan dalam pembelajaran bahasa Indonesia, sehingga pelajaran bahasa Indonesia yang selama ini dianggap sangat sulit menjadi membosankan. Menurut Lie (2002), pendidik perlu menyusun dan melaksanakan kegiatan belajar mengajar berdasarkan pokok pemikiran sebagai berikut; a) pengetahuan ditentukan, dibentuk dan dikembangkan oleh siswa, b) siswa membangun pengetahuan secara aktif, c) pengajar perlu mengembangkan kompetensi dan kemampuan siswa, dan d) pendidik adalah interaksi pribadi di antara para siswa dan interaksi antara guru dan siswa

Kelancaran interaktif dalam kegiatan belajar dan mengajar suasana kelas perlu direncanakan dan dibangun sedemikian rupa, sehingga siswa mendapatkan kesempatan untuk berinteraksi satu sama lain. Oleh karena itu, pengajar perlu menciptakan suasana belajar yang sedemikian rupa, sehingga siswa bekerja sama secara gotong royong. Model pembelajaran yang memberikan kesempatan kepada siswa untuk bekerja sama dengan siswa lain dalam tugas terstruktur disebut model 
pembelajaran gotong royong atau cooperatif learning. Dalam model ini guru hanya bertindak sebagai fasilisator. Berdasarkan hasil observasi awal peneliti pada siswa kelas III SD Negeri 25 Lubuklinggau pada tahun pelajaran 2014/2015, diketahui bahwa anak kelas III Negeri 25 Lubuklinggau secara umum belum dapat menggunakan bahasa Indonesia yang baik dan benar seperti yang diharapkan dalam tujuan pembelajaran yang tercantum dalam satuan pembelajaran, khususnya dalam menentukan unsur-unsur intrinsik cerita rakyat. Berdasarkan studi pendahuluan didapat bahwa hasil belajar yang dicapai siswa tidak mencapai tingkat Kriteria Ketuntasan Mengajar (KKM) yang ditetapkan yaitu 65 hanya mencapai $45 \%$ dari jumlah siswa yang ada dan rata-rata nilai ulangan harian siswa hanya mencapai 50 sebesar $55 \%$.

Hal ini diakibatkan motivasi belajar dan tingkat kemampuan siswa menyerap materi pelajaran masih rendah serta banyak di antara siswa yang malas mengerjakan tugas, karena merasa tidak ada tantangan untuk mengerjakannya, sehingga tidak jarang tugas tersebut bukan hasil sendiri melainkan didapat dari mencontoh pekerjaan orang lain. Rendahnya nilai ulangan tersebut disebabkan oleh kurangnya pengalaman menentukan unsur-unsur intrinsik yang ada dalam sebuah cerita rakyat dan kurang menariknya metode yang digunakan. Suatu metode kadang diterapkan dalam pengajaran di SD Negeri 25 Lubuklinggau namun metode yang digunakan kurang tepat, kurang sesuai dengan materi yang diajarkan. Sehingga siswa kurang termotivasi untuk belajar.

Keberhasilan dalam pembelajaran sangat ditentukan oleh faktor guru namun tidak menutup kemungkinan faktor siswa dan lingkungan juga mempengaruhi keberhasilan tersebut. Proses pembelajaran dapat berlangsung dengan baik apabila guru dapat memilih metode pembelajaran. Menurut Djamarah dan Zein (1995) "Metode mengajar yang dapat dipilih guru harus disesuaikan dengan tujuan dan kondisi prikologi anak didik" Salah satunya adalah metode mengajar yang menggunakan model pembelajaran kooperatif. Banyak metode belajar mengajar yang bisa digunakan dalam pembelajaran kooperatif, di antaranya adalah tipe think-pairshare. Pada teknik ini siswa dibagi dalam kelompok yang terdiri dari empat orang. Setelah guru memberikan tugas, siswa akan memikirkan tugas itu sendiri kemudian dalam rentang waktu yang diberikan siswa itu akan berdiskusi dengan salah satu teman dalam kelompoknya, lalu diskusi dalam kelompok berempat dan selanjutnya berbagi dengan seluruh kelas. Teknik ini jelas sekali sangat menuntut siswa untuk aktif dalam belajar dan diskusi.

\section{METODE PENELITIAN}

Penelitian ini dilaksanakan di SD Negeri 25 Lubuklinggau. Subjek penelitian ini adalah siswa kelas III SD Negeri 25 Lubuklinggau pada semester ganjil tahun 
pelajaran 2014/2015, berjumlah 36 siswa yang terdiri dari 20 siswa perempuan dan 16 siswa laki-laki. Penelitian tindakan kelas ini dilaksanakan di SD Negeri 25 Lubuklinggau. Waktu penelitian akan dilakukan pada semester ganjil yaitu para siklus dilaksanakan pada tanggal 7 Oktober 2014, siklus I dilaksanakan pada tanggal 14 Oktober 2014 dan siklus II dilaksanakan pada tanggal 21 Oktober 2014.

Penelitian tindakan kelas ini direncanakan terdiri dari dua siklus setiap siklus terdiri dari empat tahapan yaitu perencanaan, pelaksanaan, pengamatan dan refleksi. Pihak yang membantu dalam penelitian ini adalah Bapak Marzuki, S.Pd. (sebagai kepala sekolah) dan Ibu Tri Febriyani, S.Pd.SD (sebagai supervisor dan guru pamong). Penelitian Tindakan Kelas (PTK) ini dilakukan dua siklus dengan 2 kali pertemuan setiap siklus. Pelaksanaan siklus ini meliputi empat tahap yaitu tahap perencanaan, pelaksanaan tindakan, pengamatan, dan refleksi.

Dalam menentukan keberhasilan PTK ini peneliti akan mengevaluasi hasil belajar siswa dalam menentukan unsur-unsur intrinsik cerita rakyat dengan tes esai sebanyak 5 soal. Rumus yang digunakan dalam menentukan nilai yang diperoleh siswa adalah

$$
\text { Nilai }=\frac{\text { Skor Soal }}{\text { Skor Maksimal }} \times 100 \quad \text { (Depdikbud, 1997) }
$$

Sedangkan untuk mengetahui ketuntasan hasil belajar siswa secara umum dalam menentukan unsur-unsur intrinsik cerita rakyat, peneliti mempersentasekan jumlah siswa yang mendapat nilai (KKM) 65 ke atas dengan menggunakan rumus persentase sebagai berikut :

$$
X=\frac{T}{M} \times 100 \% \quad \text { (Depdikbud, 1997) }
$$

Keterangan :

$\mathrm{X}=$ Persentase ketuntasan belajar klasikal

$\mathrm{T}=\quad$ Jumlah siswa yang tuntas belajar

$\mathrm{M}=$ Jumlah seluruh siswa dalam kelas

Untuk mengetahui adanya peningkatan pada setiap pengambilan data tes dimulai dari tes pratindakan hingga akhir siklus penelitian, peneliti menggunakan rumus sebagai berikut :

$X=\frac{R_{2}-R_{1}}{R_{1}} \times 100 \% \quad$ (Depdikbud, 1997) 
Keterangan :

$\mathrm{X}=$ Persentase peningkatan hasil tindakan

R1 = Nilai rata-rata sebelum tindakan (pratindakan)

R2 = Nilai rata-rata setelah siklus I dan siklus II

Apabila penelitian ini sesuai dengan kriteria pengujian hipotesis atau kriteria keberhasilan yang ditetapkan, maka model pembelajaran kooperatif tipe think pair share ini dapat digunakan untuk meningkatkan kemampuan menentukan unsur-unsur intrinsik dalam cerita rakyat pada siswa kelas III SD Negeri 25 Lubuklinggau. Penetapan indikator keberhasilan ini berpedoman pada kriteria belajar tuntas yang ditetapkan di SD Negeri 25 Lubuklinggau yaitu secara individu siswa memperoleh nilai KKM sebesar 65 atau mencapai $65 \%$ dan secara klasikal yang memperoleh nilai 65 mencapai 85\%, berarti belajar telah tuntas. Untuk keperluan praktis kita menentukan bobot atau besarnya porsi aspek dalam menentukan unsur-unsur intrinsik cerita rakyat.

Idealnya pembobotan ini mencerminkan tingkat pentingnya masing-masing unsur dalam menentukan unsur-unsur intrinsik cerita rakyat tersebut. Dengan demikian unsur yang paling penting diberikan bobot yang lebih tinggi (Marpuang, 2002). Perhitungan unsur-unsur yang dinilai dan hasil penelitian, proses dan hasil tulisan siswa, maka tindakan pembelajaran dinyatakan berhasil menurut KKM SD Negeri 25 Lubuklinggau pada mata pelajaran Bahasa Indonesia, bila para siswa telah mendapat daya serap individu $65 \%$ nilai 65 dan daya serap secara klasikal mendapat $85 \%$ atau yang telah mencapai nilai 65 .

\section{HASIL PENELITIAN}

\section{Deskripsi Kondisi Awal}

Pengambilan data Pra Siklus pada tanggal 7 Oktober 2017 di kelas III SD Negeri 25 Lubuklinggau. Untuk memperoleh data, peneliti memberikan tes yang berupa tugas menentukan unsur-unsur intrinsik pada cerita rakyat. Selanjutnya dalam pengelolaan data yang diperoleh didapat nilai per siswa. Hasil pengamatan dan penelitian terhadap kemampuan menentukan unsur-unsur intrinsik pada cerita rakyat pada saat Berdasarkan hasil nilai Pra Siklus (terlampir) dapat dilihat bahwa siswa yang mendapat nilai lebih dari 65 (tuntas) dalam tes awal ini sebanyak 21 siswa $(58,33 \%)$ dan yang nilainya kurang dari 65 (belum tuntas) adalah 15 siswa (41,67\%). Nilai yang tertinggi adalah 75 dan yang terendah adalah 45. Rata-rata nilai secara keseluruhan sebesar 61,25. 
Tabel 1

Format Hasil Belajar Pratindakan

\begin{tabular}{|c|c|c|c|c|c|}
\hline \multirow[b]{2}{*}{ No } & \multirow[b]{2}{*}{ Nama Siswa } & \multirow[b]{2}{*}{$\mathrm{L} / \mathrm{P}$} & \multirow[b]{2}{*}{ Nilai } & \multicolumn{2}{|c|}{ Keterangan } \\
\hline & & & & Tuntas & $\begin{array}{l}\text { Belum } \\
\text { Tuntas }\end{array}$ \\
\hline 1. & Ah. Reyfan Nuguho & $\mathrm{L}$ & 65 & $\sqrt{ }$ & \\
\hline 2. & Aisya Permata Ramadahni & $\mathrm{P}$ & 65 & $\sqrt{ }$ & \\
\hline 3. & Alkhadi Fabiansyah & $\mathrm{L}$ & 65 & $\sqrt{ }$ & \\
\hline 4. & Annisa Salsabila & $\mathrm{P}$ & 45 & & $\sqrt{ }$ \\
\hline 5. & Bilqis Husna Hendra & $\mathrm{P}$ & 45 & & $\sqrt{ }$ \\
\hline 6. & Dhea Amanda Wiranti & $\mathrm{P}$ & 75 & $\sqrt{ }$ & \\
\hline 7. & Enjeliza & $\mathrm{P}$ & 75 & $\sqrt{ }$ & \\
\hline 8. & Fitri Ariyani & $\mathrm{P}$ & 55 & & $\sqrt{ }$ \\
\hline 9. & Ghina Adilla Zulfa & $\mathrm{P}$ & 55 & & $\sqrt{ }$ \\
\hline 10. & Iis Okta Ivani & $\mathrm{P}$ & 50 & & $\sqrt{ }$ \\
\hline 11. & Keysa Laura & $\mathrm{P}$ & 50 & & $\sqrt{ }$ \\
\hline 12. & Muh. Faiz Arifai & $\mathrm{L}$ & 65 & $\sqrt{ }$ & \\
\hline 13. & Marcel Putra Satria & $\mathrm{L}$ & 65 & $\sqrt{ }$ & \\
\hline 14. & Muh. Khadafi & $\mathrm{L}$ & 65 & $\sqrt{ }$ & \\
\hline 15. & Muh. Raffi & $\mathrm{L}$ & 70 & $\sqrt{ }$ & \\
\hline 16. & Nabila Clara Olivia & $\mathrm{P}$ & 70 & $\sqrt{ }$ & \\
\hline 17. & Nazwa Auravia & $\mathrm{P}$ & 55 & & $\sqrt{ }$ \\
\hline 18. & Nazwa Kirana & $\mathrm{P}$ & 55 & & $\sqrt{ }$ \\
\hline 19. & Neky Septiawan & $\mathrm{P}$ & 70 & $\sqrt{ }$ & \\
\hline 20. & Nova Fadilla & $\mathrm{P}$ & 70 & $\sqrt{ }$ & \\
\hline 21. & Muh. Vito Alfarez & $\mathrm{L}$ & 65 & $\sqrt{ }$ & \\
\hline 22. & Okta Suginto Saputra & $\mathrm{L}$ & 65 & $\sqrt{ }$ & \\
\hline 23. & Pupita Sari & $\mathrm{P}$ & 55 & & $\sqrt{ }$ \\
\hline 24. & Raihan Pratama & $\mathrm{L}$ & 55 & & $\sqrt{ }$ \\
\hline 25. & Rangga & $\mathrm{L}$ & 70 & $\sqrt{ }$ & \\
\hline 26. & Rayham Rizki & $\mathrm{L}$ & 70 & $\sqrt{ }$ & \\
\hline 27. & Rendy Jovian Ardana & $\mathrm{L}$ & 65 & $\sqrt{ }$ & \\
\hline 28. & Revan Marcelino & $\mathrm{L}$ & 65 & $\sqrt{ }$ & \\
\hline 29. & Shafira Aqila Annara & $\mathrm{P}$ & 60 & & $\sqrt{ }$ \\
\hline 30. & Yofan Depinza Saputra & $\mathrm{L}$ & 60 & & $\sqrt{ }$ \\
\hline 31. & Kodri Maulana & $\mathrm{L}$ & 65 & $\sqrt{ }$ & \\
\hline 32. & Winda Purnama Sari & $\mathrm{P}$ & 65 & $\sqrt{ }$ & \\
\hline 33. & Yuliana & $\mathrm{P}$ & 65 & $\sqrt{ }$ & \\
\hline 34. & Okta & $\mathrm{P}$ & 55 & & $\sqrt{ }$ \\
\hline 35. & Riska Dwi Utami & $\mathrm{P}$ & 50 & & $\sqrt{ }$ \\
\hline 36. & Okta Arianto & $\mathrm{P}$ & 45 & & $\sqrt{ }$ \\
\hline & Jumlah & & 2205 & 21 & \\
\hline & Rata-rata & & 61,25 & & 15 \\
\hline & Persentase Ketuntasan Belajar & & $\mathbf{5 8 , 3 3 \%}$ & & \\
\hline
\end{tabular}


Secara deskriptif dapat dikatakan bahwa kemampuan awal siswa belum termasuk kategori tuntas, karena nilai rata-ratanya kurang dari 65 dan belum mencapai ketuntasan klasikal 65 sebesar 85\%. Berikut kami sajikan rekapitulasi nilai Pra Siklus:

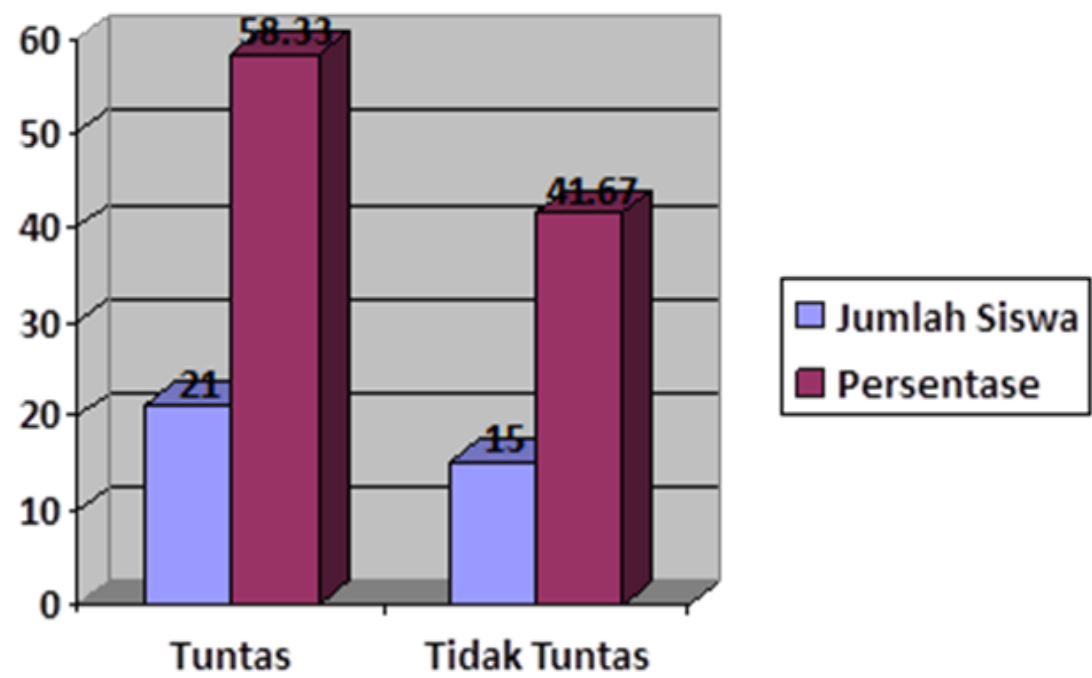

Grafik 1. Rekapitulasi Nilai Siswa Para Siklus

Rendahnya nilai tes pada tindakan awal ini disebabkan antara lain, penggunaan metode pembelajaran masih menggunakan metode ceramah, jadi siswa merasa bosan, kurang berminat, dan tidak aktif dalam proses KBM-nya. Atas dasar temuan ini peneliti menyimpulkan bahwa untuk mencapai hasil belajar yang baik, diperlukan satu metode yang dapat menarik minat siswa untuk aktif dalam proses KBM sehingga belajar akan terlihat efisien. Oleh karena itu peneliti mencoba menerapkan model pembelajaran kooperatif.

\section{Kondisi Hasil Siklus I}

Siklus I dilaksanakan 1 kali pertemuan ( 3 x 35 menit) yaitu pada tanggal 14 Oktober 2014 di kelas III SD Negeri 25 Lubuklinggau. Pada tindakan pertama ini peneliti melakukan kegiatan pembelajaran dengan penerapan model pembelajaran kooperatif tipe TPS. Hal ini diterapkan sebagai langkah awal untuk meningkaan kemampuan siswa dalam menentukan unsur-unsur intrinsik pada cerita rakyat. Hasil pelaksanaan tindakan siklus I 
Tabel 2

Format Hasil Belajar Siklus I

\begin{tabular}{|c|c|c|c|c|c|}
\hline \multirow[b]{2}{*}{ No } & \multirow[b]{2}{*}{ Nama Siswa } & \multirow[b]{2}{*}{$\mathbf{L} / \mathbf{P}$} & \multirow[b]{2}{*}{ Nilai } & \multicolumn{2}{|c|}{ Keterangan } \\
\hline & & & & Tuntas & $\begin{array}{l}\text { Belum } \\
\text { Tuntas } \\
\end{array}$ \\
\hline 1. & Ah. Reyfan Nuguho & $\mathrm{L}$ & 75 & $\sqrt{ }$ & \\
\hline 2. & Aisya Permata Ramadahni & $\mathrm{P}$ & 70 & $\sqrt{ }$ & \\
\hline 3. & Alkhadi Fabiansyah & $\mathrm{L}$ & 70 & $\sqrt{ }$ & \\
\hline 4. & Annisa Salsabila & $\mathrm{P}$ & 50 & & $\sqrt{ }$ \\
\hline 5. & Bilqis Husna Hendra & $\mathrm{P}$ & 50 & & $\sqrt{ }$ \\
\hline 6. & Dhea Amanda Wiranti & $\mathrm{P}$ & 80 & $\sqrt{ }$ & \\
\hline 7. & Enjeliza & $\mathrm{P}$ & 80 & $\sqrt{ }$ & \\
\hline 8. & Fitri Ariyani & $\mathrm{P}$ & 60 & & $\sqrt{ }$ \\
\hline 9. & Ghina Adilla Zulfa & $\mathrm{P}$ & 60 & & $\sqrt{ }$ \\
\hline 10. & Iis Okta Ivani & $\mathrm{P}$ & 55 & & $\sqrt{ }$ \\
\hline 11. & Keysa Laura & $\mathrm{P}$ & 50 & & $\sqrt{ }$ \\
\hline 12. & Muh. Faiz Arifai & $\mathrm{L}$ & 70 & $\sqrt{ }$ & \\
\hline 13. & Marcel Putra Satria & $\mathrm{L}$ & 70 & $\sqrt{ }$ & \\
\hline 14. & Muh. Khadafi & $\mathrm{L}$ & 70 & $\sqrt{ }$ & \\
\hline 15. & Muh. Raffi & $\mathrm{L}$ & 80 & $\sqrt{ }$ & \\
\hline 16. & Nabila Clara Olivia & $\mathrm{P}$ & 80 & $\sqrt{ }$ & \\
\hline 17. & Nazwa Auravia & $\mathrm{P}$ & 65 & $\sqrt{ }$ & \\
\hline 18. & Nazwa Kirana & $\mathrm{P}$ & 60 & & $\sqrt{ }$ \\
\hline 19. & Neky Septiawan & $\mathrm{P}$ & 75 & $\sqrt{ }$ & \\
\hline 20. & Nova Fadilla & $\mathrm{P}$ & 75 & $\sqrt{ }$ & \\
\hline 21. & Muh. Vito Alfarez & $\mathrm{L}$ & 70 & $\sqrt{ }$ & \\
\hline 22. & Okta Suginto Saputra & $\mathrm{L}$ & 70 & $\sqrt{ }$ & \\
\hline 23. & Pupita Sari & $\mathrm{P}$ & 65 & $\sqrt{ }$ & \\
\hline 24. & Raihan Pratama & $\mathrm{L}$ & 65 & $\sqrt{ }$ & \\
\hline 25. & Rangga & $\mathrm{L}$ & 75 & $\sqrt{ }$ & \\
\hline 26. & Rayham Rizki & $\mathrm{L}$ & 75 & $\sqrt{ }$ & \\
\hline 27. & Rendy Jovian Ardana & $\mathrm{L}$ & 75 & $\sqrt{ }$ & \\
\hline 28. & Revan Marcelino & $\mathrm{L}$ & 65 & $\sqrt{ }$ & \\
\hline 29. & Shafira Aqila Annara & $\mathrm{P}$ & 65 & $\sqrt{ }$ & \\
\hline 30. & Yofan Depinza Saputra & $\mathrm{L}$ & 65 & $\sqrt{ }$ & \\
\hline 31. & Kodri Maulana & $\mathrm{L}$ & 70 & $\sqrt{ }$ & \\
\hline 32. & Winda Purnama Sari & $\mathrm{P}$ & 65 & $\sqrt{ }$ & \\
\hline 33. & Yuliana & $\mathrm{P}$ & 65 & $\sqrt{ }$ & \\
\hline 34. & Okta & $\mathrm{P}$ & 55 & & $\sqrt{ }$ \\
\hline 35. & Riska Dwi Utami & $\mathrm{P}$ & 55 & & $\sqrt{ }$ \\
\hline 36. & Okta Arianto & $\mathrm{P}$ & 50 & & $\sqrt{ }$ \\
\hline & Jumlah & & 2395 & 26 & \\
\hline & Rata-rata & & 66,53 & & 10 \\
\hline & Persentase Ketuntasan Belajar & & $72,22 \%$ & & \\
\hline
\end{tabular}


Berdasarkan hasil nilai tindakan siklus I (terlampir) dapat dilihat bahwa siswa yang mendapat nilai lebih dari 65 (tuntas) dalam tes ini sebanyak 26 siswa $(72,22 \%)$ dan yang nilainya kurang dari 65 (belum tuntas) adalah 10 siswa (27,78\%). Nilai yang tertinggi adalah 80 dan yang terendah adalah 50. Rata-rata nilai secara keseluruhan sebesar 66,53. Jadi secara deskriptif dapat dikatakan bahwa siklus I siswa belum termasuk kategori tuntas, karena belum mencapai ketuntasan klasikal 65 sebesar 85\%. Berikut kami sajikan rekapitulasi nilai Siklus I sebagai berikut:

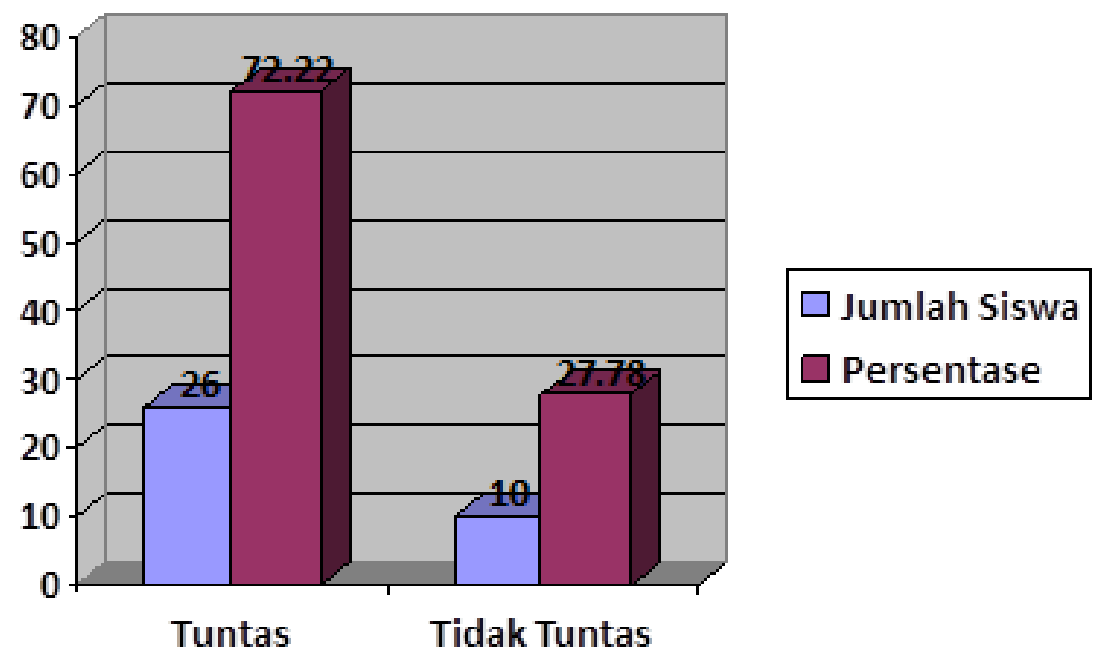

Grafik 2 Rekapitulasi Nilai Siswa Siklus I

Namun terjadi peningkatan belajar siswa dari Pra Siklus ke siklus I, hal ini terlihat pada nilai rata-rata Pra Siklus sebesar 61,25 sedangkan pada nilai rata-rata siklus I sebesar 66,53 berarti terjadi peningkatan sebesar 5,28 pada Pra Siklus ketuntasan belajar siswa sebanyak 21 siswa $(58,33 \%)$ dan pada siklus I siswa yang tuntas berjumlah 26 orang $(72,22 \%)$. Inipun dapat dilihat terjadi peningkatan yang signifikan sebasar $8,62 \%$. Secara kuatitatif hasil rata-rata tes akhir siklus I telah meningkat dari 61,25 ke 66,53 yaitu 5,28 (8,62\%). Walaupun hasil akhir siklus I mengalami peningkatan dari rata-rata Pra Siklus, peningkatan itu belum memenuhi daya serap klasikal yaitu : $\quad$ x $100 \%=72,22 \%$. Dengan demikian, hasil tindakan siklus I perlu ditingkatkan.

Berdasarkan hasil observasi para pengamat secara umum pelaksanaan pembelajaran berjalan dengan baik. Walaupun dalam proses pembelajaran yang dilakukan peneliti masih memiliki kelemahan, terutama pada penggunaan waktu dan belum adanya alat peraga. Waktu menjadi kurang efisien karena ketika menjelaskan contoh menentukan unsur-unsur intrinsik pada cerita rakyat, metode yang digunakan 
kurang efektif karena kurang sosialisasi, sehingga waktu banyak terbuang ketika siswa harus menyusun meja dan kursi untuk buat kelompok. Selain itu, pada awal proses pembelajaran guru tidak menjelaskan tujuan yang ingin dicapai dari proses pembelajaran sehingga pada awal pembelajaran siswa tidak tahu atau bingung apa yang harus dipelajari. Selain itu juga peneliti tidak membuat alat peraga seperti gambar sehingga siswa kurang tertarik sehingga keaktifan siswa dalam kelas tidak tampak. Komentar dan saran yang disampaikan para observer akan dijadikan bahan refleksi dan diterapkan pada siklus berikutnya.

Setelah dilaksanakan siklus I, peneliti memperoleh masukan-masukan atau saran-saran dari para pengamat. Untuk pelaksanaan siklus I, hal-hal yang perlu dibenahi adalah sebagai berikut : pemanfaatan waktu seefisien mungkin, mempersiapkan alat peraga, penyampaian materi yang lebih sistematis dan pemberian motivasi kepada siswa lebih ditingkatkan

\section{Kondisi Hasil Siklus II}

Siklus II ini dilaksanakan dalam 1 x pertemuan $(3$ x 35 menit) pada tanggal 21 Oktober 2014. Tahap perencanaan pada siklus II ini adalah refleksi dari siklus I, halhal yang dipersiapkan adalah sebagai berikut : menganalisis materi pengajaran, membuat program satuan pengajaran, membuat program rencana pengajaran, menyiapakan alat peraga, menyiapkan instrumen penelitian, menyiapkan lembar pengamatan dan menyusun posisi kursi dan meja siswa untuk diskusi. Untuk hasil tes yang ada telah direkapitulasi dapat dilihat pada Tabel 3.

Tabel 3

Format Hasil Belajar Siklus II

\begin{tabular}{|c|c|c|c|c|c|}
\hline \multirow[b]{2}{*}{ No } & \multirow[b]{2}{*}{ Nama Siswa } & \multirow[b]{2}{*}{$\mathrm{L} / \mathrm{P}$} & \multirow[b]{2}{*}{ Nilai } & \multicolumn{2}{|c|}{ Keterangan } \\
\hline & & & & Tuntas & $\begin{array}{l}\text { Belum } \\
\text { Tuntas }\end{array}$ \\
\hline 1. & Ah. Reyfan Nuguho & $\mathrm{L}$ & 80 & $\sqrt{ }$ & \\
\hline 2. & Aisya Permata Ramadahni & $\mathrm{P}$ & 80 & $\sqrt{ }$ & \\
\hline 3. & Alkhadi Fabiansyah & $\mathrm{L}$ & 80 & $\sqrt{ }$ & \\
\hline 4. & Annisa Salsabila & $\mathrm{P}$ & 60 & & \\
\hline 5. & Bilqis Husna Hendra & $\mathrm{P}$ & 60 & & \\
\hline 6. & Dhea Amanda Wiranti & $\mathrm{P}$ & 95 & $\sqrt{ }$ & \\
\hline 7. & Enjeliza & $\mathrm{P}$ & 95 & $\sqrt{ }$ & \\
\hline 8. & Fitri Ariyani & $\mathrm{P}$ & 70 & $\sqrt{ }$ & \\
\hline 9. & Ghina Adilla Zulfa & $\mathrm{P}$ & 70 & $\sqrt{ }$ & \\
\hline 10. & Iis Okta Ivani & $\mathrm{P}$ & 65 & $\sqrt{ }$ & \\
\hline 11. & Keysa Laura & $\mathrm{P}$ & 65 & $\sqrt{ }$ & \\
\hline 12. & Muh. Faiz Arifai & $\mathrm{L}$ & 75 & $\sqrt{ }$ & \\
\hline & Marcel Putra Satria & $\mathrm{L}$ & 75 & $\sqrt{ }$ & \\
\hline 14. & Muh. Khadafi & $\mathrm{L}$ & 75 & $\sqrt{ }$ & \\
\hline
\end{tabular}




\begin{tabular}{lllll} 
15. & Muh. Raffi & $\mathrm{L}$ & 95 & $\sqrt{ }$ \\
\hline 16. & Nabila Clara Olivia & $\mathrm{P}$ & 95 & $\sqrt{ }$ \\
\hline 17. & Nazwa Auravia & $\mathrm{P}$ & 70 & $\sqrt{ }$ \\
\hline 18. & Nazwa Kirana & $\mathrm{P}$ & 70 & $\sqrt{ }$ \\
\hline 19. & Neky Septiawan & $\mathrm{P}$ & 95 & $\sqrt{ }$ \\
\hline 20. & Nova Fadilla & $\mathrm{P}$ & 95 & $\sqrt{ }$ \\
\hline 21. & Muh. Vito Alfarez & $\mathrm{L}$ & 75 & $\sqrt{ }$ \\
\hline 22. & Okta Suginto Saputra & $\mathrm{L}$ & 75 & $\sqrt{ }$ \\
\hline 23. & Pupita Sari & $\mathrm{P}$ & 70 & $\sqrt{ }$ \\
\hline 24. & Raihan Pratama & $\mathrm{L}$ & 70 & $\sqrt{ }$ \\
\hline 25. & Rangga & $\mathrm{L}$ & 80 & $\sqrt{ }$ \\
\hline 26. & Rayham Rizki & $\mathrm{L}$ & 80 & $\sqrt{ }$ \\
\hline 27. & Rendy Jovian Ardana & $\mathrm{L}$ & 80 & $\sqrt{ }$ \\
\hline 28. & Revan Marcelino & $\mathrm{L}$ & 75 & $\sqrt{ }$ \\
\hline 29. & Shafira Aqila Annara & $\mathrm{P}$ & 70 & $\sqrt{ }$ \\
\hline 30. & Yofan Depinza Saputra & $\mathrm{L}$ & 70 & $\sqrt{ }$ \\
\hline 31. & Kodri Maulana & $\mathrm{L}$ & 75 & $\sqrt{ }$ \\
\hline 32. & Winda Purnama Sari & $\mathrm{P}$ & 75 & $\sqrt{ }$ \\
\hline 33. & Yuliana & $\mathrm{P}$ & 75 & $\sqrt{ }$ \\
\hline 34. & Okta & $\mathrm{P}$ & 65 & $\sqrt{ }$ \\
\hline 35. & Riska Dwi Utami & $\mathrm{P}$ & 65 & $\sqrt{ }$ \\
\hline 36. & Okta Arianto & $\mathrm{P}$ & 60 & \\
\hline & Jumlah & & 2725 & 33 \\
\hline & Rata-rata & & 75,69 & \\
\hline & Persentase Ketuntasan Belajar & & $\mathbf{9 1 , 6 7 \%}$ & \\
\hline & & & \\
\hline
\end{tabular}

Berdasarkan hasil nilai tindakan siklus II (terlampir) dapat dilihat bahwa siswa yang mendapat nilai lebih dari 65 (tuntas) dalam tes ini sebanyak 36 siswa (91,67\%) dan yang nilainya kurang dari 65 (belum tuntas) adalah 3 siswa (8,33\%). Nilai yang tertinggi adalah 95 dan yang terendah adalah 60. Rata-rata nilai secara keseluruhan sebesar 75,69. Jadi secara deskriptif dapat dikatakan bahwa siklus II siswa sudah termasuk kategori tuntas, karena nilai rata-ratanya lebih dari 65 dan memenuhi daya serap klasikal yaitu : $\quad$ x 100\% $=91,67 \%$. Dengan demikian, tindakan siklus III tidak perlu lagi dilaksanakan. Berikut kami sajikan rekapitulasi nilai Siklus II sebagai berikut:

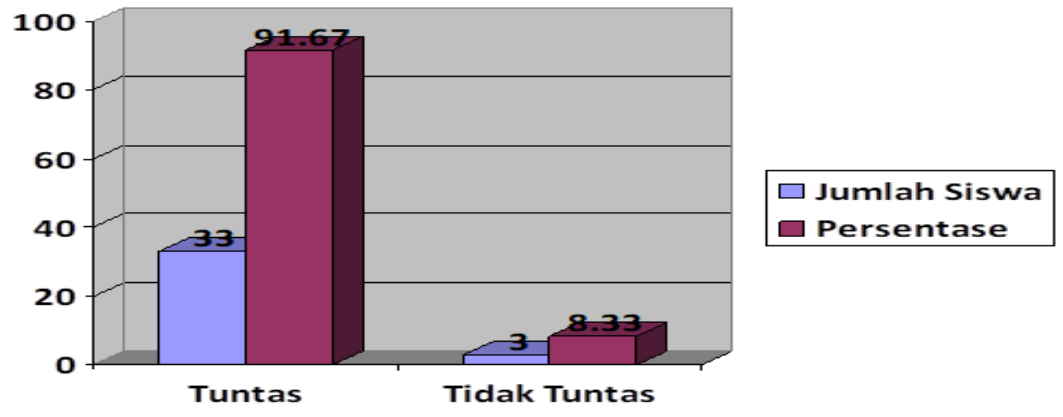

Grafik 3. Rekapitulasi Nilai Siswa Siklus II 


\section{PEMBAHASAN}

Kesulitan dalam menentukan unsur-unsur intrinsik pada cerita rakyat pada siklus I tidak terjadi lagi pada siklus II. Pada siklus II ini siswa mengalami peningkatan dalam menentukan unsur-unsur intrinsik pada cerita rakyat, walaupun ada sebagian kecil siswa yang masih kesulitan dalam menentukan unsur-unsur intrinsik pada cerita rakyat.

Pelaksanaan siklus II pada penelitian ini diamati oleh 2 orang pengamat yaitu Bapak Marzuki, S.Pd. (Kepala SD Negeri 25 Lubuklinggau), Ibu Tri FerriyaniS.Pd.SD. (Guru Kelas III SD Negeri 25 Lubuklinggau). Berdasarkan hasil pengamatan di atas dapat disimpukan bahwa secara umum proses belajar mengajar dengan penerapan model pembelajaran kooperatif tipe TPS dapat meningkatkan aktivitas belajar siswa. Hal ini dapat dilihat pada antusiasnya siswa dalam menerima pelajaran serta siswa lebih merespon pertanyaan-pertanyaan yang diajukan oleh guru.

Pelaksanaan kegiatan belajar mengajar dengan menggunakan model pembelajaran kooperatif tipe TPS pada siklus II menunjukkan adanya peningkatan, antara lain siswa lebih aktif jika dibandingkan dengan pelaksanaan siklus I. Siswa bersemangat dan aktif dalam kegiatan belajar, secara umum siswa memiliki antusias yang tinggi dalam berdiskusi. Melihat suasana pembelajaran yang aktif, maka dapat disimpulkan bahwa model pembelajaran kooperatif tipe TPS dapat meningkatn kemampuan siswa dalam menentukan unsur-unsur intrinsik pada cerita rakyat. Keaktifan siswa dalam kegiatan pembelajaran tersebut menandakan indikator kegiatan pembelajaran telah mencapai yang diinginkan.

Pada siklus II ini rata-rata hasil tes sebesar 75,69 bila dibandingkan dengan nilai rata-rata hasil siklus I sebesar 66,53 meningkat sebesar 9,16 atau 13,77\%. Jumlah siswa yang tuntas belajar pada siklus II adalah sebanyak 33 orang $(91,67 \%)$ sedangkan pada siklus I sebanyak 26 orang $(72,22 \%)$. Dengan demikian, terdapat peningkatan siswa yang tuntas sebanyak 7 orang $(19,75 \%)$. Oleh sebab itu, tindakan siklus berikutnya tidak perlu dilaksanakan, karena kriteria ketuntasan secara klasikal $85 \%$ pada tindakan siklus II ini telah tercapai. Keberhasilan tersebut dapat dicapai dengan memperbaiki kekurangan-kekurangan dalam proses pembelajaran siklus I dan penerapan hasil koodinasi dengan dosen pembimbing dan para pengamat dalam penelitian sehingga nilai yang dicapai siswa memperoleh ketuntasan baik secara individu maupuan secara klasikal.

Sebelum melakukan tindakan pertama, terlebih dahulu peneliti mengadakan refleksi awal (Pra Siklus) untuk mengetahui permasalahan yang sebenarnya. Untuk memperoleh data, peneliti memberikan tes yang berupa soal menentukan unsur-unsur intrinsik pada cerita rakyat. Selanjutnya data akan diolah untuk melihat persentase anak yang tuntas dan yang belum tuntas. Setelah pengolahan data dilakukan dapat dilihat bahwa siswa yang mendapat nilai lebih dari 65 (tuntas) dalam tes awal ini 
sebanyak 21 siswa $(58,33 \%)$ dan yang nilainya kurang dari 65 (belum tuntas) adalah 15 siswa $(41,67 \%)$. Nilai yang tertinggi adalah 75 dan yang terendah adalah 45 . Ratarata nilai secara keseluruhan sebesar 61,25. Jadi, secara deskriptif dapat dikatakan bahwa kemampuan awal siswa belum termasuk kategori tuntas, karena nilai rataratanya kurang dari 65 dan belum mencapai ketuntasan klasikal 65 sebesar 85\%.

Rendahnya hasil pada refeksi awal atau Pra Siklus dikarenakan penggunaan metode pengajaran yang digunakan selama ini masih kurang efektif dan tepat guna. Metode yang digunakan adalah metode ceramah yang diselingi dengan metode tanya jawab. Metode ini tidak mendukung tercapainya kemampuan siswa untuk menentukan unsur-unsur intrinsik pada cerita rakyat dikarenakan metode tersebut kurang dapat membangkitkan motivasi siswa.

Siklus I dilakukan untuk memperbaiki kondisi awal hasil belajar anak. Untuk itu pada proses pembelajaran anak diterapkan model pembelajaran kooperatif tipe TPS. Proses kegiatan pembelajaran pada siklus I ini siswa belum begitu sempurna dalam mengikuti pembelajaran. Selain itu apersepsi perlu dipertajam, memperjelas penjelasan materi, meningkatkan motivasi siswa, media papan tulis harus digunakan, ulas kembali hasil latihan siswa dan masih ada beberapa siswa kurang memahami pembelajaran.

Untuk mengetahui keberhasilan siswa pada tindakan pertama ini digunakan beberapa soal dalam menentukan unsur-unsur intrinsik pada cerita rakyat. Berdasarkan data nilai yang diperoleh (terlampir) menunjukkan bahwa siswa yang memperoleh nilai di atas 65 berjumlah 26 siswa atau 72,22\%. Hal ini berarti tujuan pembelajaran secara klasikal $(85 \%)$ belum tercapai. Setelah dilaksanakan siklus I ini terlihat adanya banyak perubahan dan peningkatan aktivitas siswa dalam mengikuti pembelajaran. Ini terlihat pada Pra Siklus hanya 21 siswa yang tuntas setelah diadakan siklus I meningkat menjadi 26 siswa.

Pada siklus II ini suasana kelas sangat mendukung pencapaian tujuan pembelajaran, dengan motivasi guru bersemangat dan aktif dalam kegiatan belajar, terjadi interaksi antara siswa dengan siswa dan antara guru dengan siswa. Keaktifan siswa dalam kegiatan pembelajaran tersebut mendeskripsikan kegiatan pembelajaran telah mencapai sasaran yang dinginkan. Hal ini pun didukung hasil jawaban siswa yang pada tes siklus II menunjukkan sebanyak 33 siswa yang tuntas dari 36 jumlah siswa dengan klasikal ketuntasan 91,67\%. Hal ini menggambarkan bahwa model pembelajaran kooperatif tipe TPS dapat meningkatkan motivasi dan hasil belajar siswa pada materi menentukan unsur-unsur intrinsik cerita rakyat.

Hasil belajar siswa kelas III SD Negeri 25 Lubuklinggau dalam menentukan unsur-unsur intrinsik cerita rakyat setelah dilakukan penerapan model pembelajaran kooperatif tipe TPS peneliti paparkan bahwa hasil tes Pra Siklus, hasil tes tindakan siklus I, hasil tes tindakan siklus II terjadi peningkatan. Peningkatan tersebut yaitu 
peningkatan jumlah siswa yang tuntas belajar dan peningkatan nilai rata-rata hasil tes, rekapitulasinya dapat dilihat di Tabel 4.4 di bawah ini :

Tabel 4

Perbandingan Ketuntasan Belajar dan Presentase Ketuntasan Dalam Tindakan Penelitian

\begin{tabular}{|c|c|c|c|c|c|c|}
\hline \multirow{2}{*}{ Nilai Hasil Tes } & \multicolumn{2}{|l|}{ Pra Siklus } & \multicolumn{2}{|l|}{ Siklus I } & \multicolumn{2}{|l|}{ Siklus II } \\
\hline & Frekuensi & Persen & Frekuensi & Persen & Frekuensi & Persen \\
\hline $65 \mathrm{ke}$ atas & 21 orang & $58,33 \%$ & 26 orang & $72,22 \%$ & 33 orang & $91,67 \%$ \\
\hline 65 ke bawah & 15 orang & $41,67 \%$ & 10 orang & $27,73 \%$ & 3 orang & $8,33 \%$ \\
\hline Jumlah & 36 orang & $100 \%$ & 36 orang & $100 \%$ & 36 orang & $100 \%$ \\
\hline Nilai rata-rata & 61,25 & & 66,53 & & 75,69 & \\
\hline
\end{tabular}

Berdasarkan tabel di atas, maka kami sajikan rekapitulasi nilai Siklus II sebagai berikut:

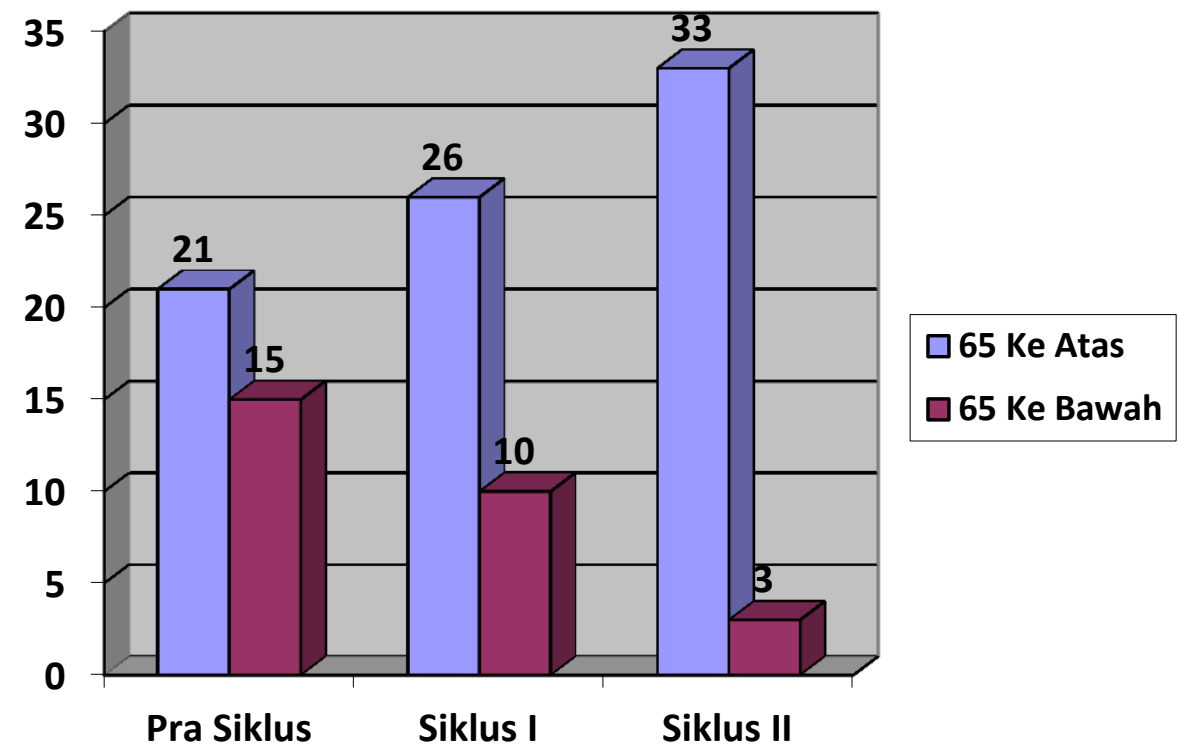

Grafik 3 Rekapitulasi Nilai Siswa Pra Siklus, Siklus I dan Siklus II

Dari tabel di atas dapat disimpulkan bahwa nilai rata-rata hasil tes pada siklus I jika dibandingkan dengan hasil tes Pra Siklus mengalami peningkatan sebesar $8,62 \%$. Sedangkan siswa yang dinyatakan tuntas pada Pra Siklus sebanyak 21 orang $(58,33 \%)$ dan pada siklus I meningkat menjadi 26 orang $(72,22 \%)$, berarti 
peningkatan siswa yang tutas dari partindakan ke siklus pertama sebanyak 5 orang. Nilai rata-rata hasil tes pada siklus kedua jika dibandingkan dengan siklus pertama juga mengalami peningkatan yaitu sebesar 9,16 atau 13,77\%. Sedangkan siswa yang tuntas dari 26 siswa pada siklus pertama meningkat menjadi 33 siswa pada siklus kedua, berarti terjadi peningkatan dari siklus pertama ke siklus kedua sebanyak 7 orang. Sedangkan perhitungan peningkatan dari Pra Siklus ke siklus II sebesar 9,86 atau 16,1\%. Dengan siswa yang tuntas pada Pra Siklus 21 orang setelah dilakukan siklus II menjadi 33 orang, berarti terjadi peningkatan dari Pra Siklus ke siklus II sebanyak 12 orang (data terlampir). Dengan demikian penerapan model pembelajaran kooperatif tipe TPS ini mampu meningkatkan kemampuan siswa kelas IV SD Negeri 25 Lubuklinggau dalam menentukan unsur-unsur intrinsik pada cerita rakyat.

\section{SIMPULAN}

Berdasarkan hasil penelitian dan pembahasan dapat disimpulkan bahwa kemampuan siswa dalam menentukan unsur-unsur intrinsik cerita rakyat mengalami peningkatan. Hal ini dapat dilihat dari rata-rata nilai pada setiap tindakan. Rata-rata nilai pratindakan sebesar 61,25, pada siklus I rata-rata nilai yang di dapat meningkat menjadi 66,53. Sedangkan hasil rata-rata pada siklus II meningkat lagi menjadi 75,69. Besarnya peningkatan kemampuan menentukan unsur-unsur intrinsik cerita rakyat melalui model pembelajaran kooperatif tipe Think Pair and Share (TPS) dari pratindakan sampai akhir siklus II sebesar $16,1 \%$.

\section{DAFTAR PUSTAKA}

Depdikbud. (1997). Garis-garis Besar Program Pengajaran. Jakarta: Balai Pustaka. Djamarah \& Zein. (1995). Strategi Belajar Mengajar. Jakarta: Rineka Cipta.

Lie, A. (2002). Cooperative Learning. Jakarta: Grasindo.

Marpaung. (2002). Model-model Pembelajaran. Jakarta : Depdiknas. 